\title{
Yield, germination and herbicide residue in seeds of preharvest desiccated wheat ${ }^{1}$
}

\author{
Lais Tessari Perboni ${ }^{2}$, Dirceu Agostinetto ${ }^{2}$, Leandro Vargas ${ }^{3}$, Joanei Cechin ${ }^{2}$, \\ Renan Ricardo Zandoná ${ }^{\text {, Humberto De Souza Farias }}{ }^{2}$
}

\begin{abstract}
The goals of this study were to evaluate herbicide application rates at different timings for preharvest desiccation of wheat (Trial 1), as well as to evaluate the effect of the timing of herbicide desiccation at preharvest and harvest timing (Trial 2) on yield, germination, and herbicide residue in wheat seed. In Trial 1, treatments consisted of two application rates of glufosinate, glyphosate, paraquat, or paraquat+diuron and a control without application; application time periods were in the milk grain to early dough stage, soft dough to hard dough stage, and hard dough stage. In Trial 2 , treatments consisted of different application time periods (milk grain to early dough stage, and soft dough to hard dough stage), different herbicides (glufosinate, 2,4-D+glyphosate, and untreated control), and different harvest times (5, 10 and 15 days after herbicide application). One thousand seeds weight, yield, first and final germination count, and herbicide residue on seeds were evaluated. Preharvest desiccation with paraquat, glufosinate, and 2,4-D+glyphosate at the milk grain to early dough stage reduces wheat yield. Regardless of the herbicide and application rate, application in the milk grain to early dough stage and soft dough to hard dough stage provides greater germination of wheat seeds, except at the lower dose of paraquat. Systemic herbicides accumulate more in wheat seeds.
\end{abstract}

Index terms: Triticum aestivum, herbicide, physiological quality, harvest aid.

\section{Produtividade, germinação e resíduo de herbicidas em sementes de trigo dessecado na pré-colheita}

\begin{abstract}
RESUMO - Os objetivos foram avaliar doses de herbicidas em diferentes épocas de dessecação pré-colheita do trigo (Experimento 1); e, o efeito de herbicidas em diferentes épocas de dessecação pré-colheita e épocas de colheita (Experimento 2) sobre a produtividade, germinação e resíduos de herbicidas em sementes de trigo. No experimento 1, os tratamentos foram: duas doses e testemunha sem aplicação dos herbicidas glufosinate, glyphosate, paraquat, paraquat+diuron; e, as épocas de aplicação foram: grão leitoso a pastoso, grão pastoso a farináceo e grão farináceo duro. No experimento 2, os tratamentos foram as épocas de aplicação: grão leitoso a pastoso e grão pastoso a farináceo; os herbicidas: glufosinate, 2,4-D+glyphosate e testemunha sem aplicação; e, as épocas de colheitas: 5, 10 e 15 dias após aplicação. Avaliaram-se massa de mil sementes, produtividade, primeira e contagem final da germinação e resíduo dos herbicidas nas sementes. A dessecação pré-colheita com paraquat, glufosinate e 2,4-D+glyphosate em estádio de grão leitoso a pastoso reduz a produtividade do trigo. Independente do herbicida e dose, aplicação em estádio de grão leitoso a pastoso e grão pastoso a farináceo proporciona maior germinação de sementes de trigo, exceto a menor dose de paraquat. Herbicidas sistêmicos acumulam-se mais nas sementes de trigo.
\end{abstract}

Termos para indexação: Triticum aestivum, herbicida, qualidade fisiológica, antecipação da colheita.

\section{Introduction}

Cultivation of super early maturing soybean cultivars in Southern Brazil mainly due to climate and disease management issues, has shifted sowing to an earlier time and, consequently, pushed wheat harvest, the main winter crop in this region, also to an earlier time (Bianchi et al., 2011). Nonselective herbicides have been applied to different crops to
${ }^{1}$ Submitted on 02/07/2018. Accepted for publication on 04/18/2018. ${ }^{2}$ Universidade Federal de Pelotas, Caixa Postal 354, 960109-000 - Pelotas, RS, Brasil.
${ }^{3}$ Embrapa Trigo - CNPT, Caixa Postal 451, 99001-970 - Passo Fundo, RS, Brasil. *Corresponding author $<$ laliperboni@hotmail.com> 
promote an early harvest and reduce interference from weeds. Only glufosinate is registered for preharvest desiccation of wheat and the application must be between the soft dough and hard dough stages (Agrofit, 2018).

The application of desiccant herbicides accelerates the process of water loss from plants and consequently from seeds, which moves up harvest time and reduces the period of prolonged exposure to factors that bring about deterioration after physiological maturity (Griffin et al., 2010). However, preharvest desiccants should be applied at the right time because applications made before the crops reach physiological maturity interfere with grain filling and seed quality (Jaskulski and Jaskulska, 2014). In addition, herbicides used during desiccation in preharvest can accumulate in seeds, reducing their vigor and germination (Jaskulski and Jaskulska, 2014; Subedi et al., 2017).

The level of herbicide residue on/in the seed depends on various factors, such as the application rate, the mode of action of the herbicide, environmental conditions, phenological stage when the herbicide is applied, pre-harvest interval, and physical/chemical characteristics of the herbicide, especially those related to persistence in the environment (Cessna and Holm, 1994; Midio and Martins, 1997; Subedi et al., 2017). Studies are lacking on preharvest desiccation of wheat in Brazil for defining application parameters (application rate, herbicide, spray mixture volume, adjuvants, and application time period), considering that they may affect herbicide accumulation and change the physiological quality of the seed. Furthermore, it should be noted that there is difficulty in correct determination of the phenological stages by farmers regarding choice of the ideal time for preharvest desiccation. Thus, the aims of this study were to evaluate the effect of the application rates of glyphosate, glufosinate, paraquat, and paraquat+diuron at different times of preharvest desiccation of wheat (Trial 1), and evaluate times of preharvest desiccation with glufosinate and 2,4-D+glyphosate and different harvest times (Trial 2) on yield, physiological quality and herbicide residue of wheat seeds.

\section{Materials and Methods}

Trial 1. Preharvest desiccation using different application rates of glyphosate, glufosinate, paraquat and paraquat+diuron at three different application time periods.

This trial was carried out in the experimental area of Embrapa Trigo in Passo Fundo, RS, Brazil, in a soil classified as a Latossolo vermelho distrófico with medium texture. The wheat cultivar BRS Parrudo was sown at a density of 300-320 seeds. $\mathrm{m}^{-2}$ in 5 $\mathrm{x} 4 \mathrm{~m}$ plots at a spacing of $0.17 \mathrm{~m}$ between rows. Sowing was carried out together with base fertilization using $200 \mathrm{~kg}$. ha ${ }^{-1}$ of the NPK formulation 5-25-25, following the recommendations for the wheat crop (Comissão Brasileira de Pesquisa de Trigo e Triticale, 2012) based on the results of soil analysis. Topdressed fertilization consisted of $100 \mathrm{~kg}$. ha- ${ }^{-1}$ of nitrogen in the form of urea split into two applications, one at the beginning of tillering and the other at the beginning of stem elongation (Comissão Brasileira de Pesquisa de Trigo e Triticale, 2012).

A randomized block experimental design was used with four replications, and treatments in a $4 \times 3 \times 3$ factorial arrangement. Factor A consisted of the herbicides glufosinate $\left(200 \mathrm{~g}\right.$ a.i. $\left.\mathrm{L}^{-1}\right)$, glyphosate $\left(360 \mathrm{~g}\right.$ a.e. $\left.\mathrm{L}^{-1}\right)$, paraquat $(200 \mathrm{~g}$ a.i. $\left.\mathrm{L}^{-1}\right)$, and paraquat+diuron $\left(200+100 \mathrm{~g}\right.$ a.i. $\left.\mathrm{L}^{-1}\right)$; factor $\mathrm{B}$ consisted of herbicide application rates: rate 0 (control without application), lower application rate $\left(1.5 \mathrm{~L}\right.$. ha $\left.{ }^{-1}\right)$, and higher application rate $\left(2.0 \mathrm{~L}\right.$. ha ${ }^{-1}$, except for glyphosate, which was 3.0 L. ha ${ }^{-1}$ ); and factor $\mathrm{C}$ compared application time periods: 1 st time period at the milk grain to soft dough stage, 2nd time period at the soft dough to hard dough stage, and 3rd time period in the hard dough stage, determined according to the maturation scale proposed by Zadoks et al. (1974).

The herbicides were applied with a knapsack sprayer, pressurized with $\mathrm{CO}_{2}$, equipped with XR 11002 spray nozzles, distributing a spray volume equivalent to $176 \mathrm{~L}$. ha ${ }^{-1}$. To prevent disease, pyraclostrobin+metconazol (Opera Ultra ${ }^{\circledR}$ - 0.7 L. ha $\left.^{-1}\right)$ and metconazol $\left(\right.$ Caramba $^{\circledR}-1.0$ L. ha $\left.{ }^{-1}\right)$ were applied (Agrofit, 2018).

Wheat was harvested in a useful area of $13.6 \mathrm{~m}^{2}$, discounting two border rows and $0.5 \mathrm{~m}$ from each end, as the herbicide treatments of each application time period reached the suitable time of harvest; that is, the wheat that underwent desiccation in the different time periods was harvested at different moments. The variables evaluated were yield, germination test, and residue analysis in the seeds. Yield was calculated by the weight of the seed obtained in the plot, with values corrected for moisture content of $13 \%$ and then extrapolated to hectare.

For the germination test, two subsamples of 50 seeds per replication of each treatment were used, distributed in rolls of Germitest ${ }^{\mathbb{}}$ paper moistened with distilled water at the rate of 2.5 times the dry weight of the substrate. The rolls formed were placed in a germinator at a temperature of $20^{\circ} \mathrm{C}$, and normal seedlings were counted on the 8th day (Brasil, 2009). Residues of glufosinate, glyphosate, and paraquat were analyzed on/in $500 \mathrm{~g}$ of samples.

Yield and germination data were subjected to analysis of variance $(p \leq 0.05)$ and, in the case of significance, the effects of application rates, application time periods, and herbicides were compared by the Duncan test. 
Trial 2. Preharvest desiccation with glufosinate and 2,4-D+glyphosate in two application time periods and three harvest timing.

This trial was performed in the experimental area of the Herbology Center of the Faculdade de Agronomia Eliseu Maciel - UFPel in the municipality of Capão do Leão, RS, Brazil, in soil classified as an Argissolo vermelho amarelo of sandy loam texture.

The cultivar Quartzo was sown at a density of 300-320 seeds. $\mathrm{m}^{-2}$ in plots of $5 \times 4 \mathrm{~m}$ and spacing of $0.17 \mathrm{~m}$ between rows. Sowing was carried out together with base fertilization using $460 \mathrm{~kg}$. ha ${ }^{-1}$ of the NPK formulation 13-13-13, following the recommendations for the wheat crop (Comissão Brasileira de Pesquisa de Trigo e Triticale, 2012) based on soil analysis. Topdressed fertilization consisted of $80 \mathrm{~kg}$. ha ${ }^{-1}$ of nitrogen in the form of urea split into two applications, one at the beginning of tillering and the other at the beginning of stem elongation (Comissão Brasileira de Pesquisa de Trigo e Triticale, 2012).

A randomized block experimental design was used with four replications and treatments in a $2 \times 3 \times 3$ factorial arrangement. Factor A consisted of application time periods: the first time period being when the seeds had a moisture content of $39.8 \%$ (between milk grain and soft dough stage), and the second time period being when the seeds had a moisture content of $28.2 \%$ (between soft dough and hard dough stage). Factor B compared the herbicides glufosinate ( $400 \mathrm{~g}$ a.i. ha $\left.{ }^{-1}\right)$, with the addition of adjuvant $(0.2 \% \mathrm{v} / \mathrm{v}), 2,4-\mathrm{D}+$ glyphosate (1005 g a.e. L. ha ${ }^{-1}+1080$ g a.e. ha $\left.{ }^{-1}\right)$, and a control without application. Factor $\mathrm{C}$ consisted of wheat harvest timing: 5, 10, and 15 days after application of the herbicides, which were designated as first, second, and third harvest, respectively.

Herbicides were applied with a knapsack sprayer, pressurized with $\mathrm{CO}_{2}$, equipped with fan type nozzles 110.015 , distributing a spray volume equivalent to $120 \mathrm{~L}$. ha ${ }^{-1}$. To prevent disease, two applications were made of trifloxystrobin
+ prothioconazole $\left(\mathrm{Fox}^{\circledR}-0.4 \mathrm{~L}\right.$. ha $\left.{ }^{-1}\right)$ with the addition of methylated soybean oil $(0.5 \% \mathrm{v} / \mathrm{v})$; and one application of trifloxystrobin + tebuconazole $\left(\mathrm{Nativo}^{\circledR}-0.75 \mathrm{~L}^{\mathrm{C}} \mathrm{ha}^{-1}\right)$ with the addition of methylated soybean oil $(0.25 \% \mathrm{v} / \mathrm{v})$ (Agrofit, 2018).

A useful area of $3.57 \mathrm{~m}^{2}$ was harvested, discounting two border rows and $0.5 \mathrm{~m}$ from each end, according to the harvest times described above. Moisture content of the harvested seeds was determined in each treatment in the two application time periods and in the three harvest time periods (Table 1). The variables evaluated were yield, 1000 seed weight, first germination count, final germination count, and herbicide residue. Yield, final germination cunt, and residue analysis were determined as in Trial 1. One thousand seed weight was determined by weighing eight subsamples of 100 seeds per plot, and the values were adjusted to $13 \%$ moisture content (Brasil, 2009). First germination count of normal seedlings was performed on the 4th day after setting up the germination experiment (Brasil, 2009). Mean data of temperature $\left({ }^{\circ} \mathrm{C}\right)$ and accumulated rainfall $(\mathrm{mm})$ in the period of conducting the Trial 1 and Trial 2 are described in Table 2.

The data of yield, 1000 seed weight, first germination count, and final germination count were subjected to analysis of variance $(p \leq 0.05)$ and, in the case of significance, the effects of herbicides and harvest timing were analyzed by the Duncan test, and the effects of application time periods by the Fisher test.

\section{Results and Discussion}

In Trial 1 , for the yield variable, interaction was found between the herbicide and application time period treatments (Table 3). Application of paraquat in the milk grain to soft dough stage reduced wheat yield compared to application of glufosinate, glyphosate, and paraquat+diuron. In relation to the effect of application time periods for each herbicide, only the application of paraquat in the milk grain to soft

Table 1. Moisture content at harvest (\%) of wheat seeds in two preharvest desiccation timing and three harvest timing.

\begin{tabular}{ccccccc}
\hline & \multicolumn{3}{c}{ Milk grain to soft dough } & \multicolumn{2}{c}{ Soft dough to hard dough } \\
\cline { 2 - 7 } & Control & Glufosinate & $2,4-\mathrm{D}+$ Glyphosate & Control & Glufosinate & $2,4-\mathrm{D}+$ Glyphosate \\
\hline H1 & 33 & 34.3 & 32.9 & 21.9 & 21.2 & 22.5 \\
H2 & 25.4 & 22.2 & 23.5 & 14.2 & 13.3 & 13.4 \\
H3 & 23.9 & 20.6 & 21.7 & 13.7 & 12.9 & 12.8 \\
\hline
\end{tabular}

${ }^{1} \mathrm{H} 1=$ first harvest; $\mathrm{H} 2$ = second harvest; H3 = third harvest.

Table 2. Mean data of temperature $\left({ }^{\circ} \mathrm{C}\right)$ and accumulated rainfall $(\mathrm{mm})$ in the period of conducting the experiments.

\begin{tabular}{|c|c|c|c|c|c|c|c|c|c|c|}
\hline \multirow[b]{2}{*}{ Month/Year } & \multicolumn{5}{|c|}{ Embrapa Trigo $^{1}$} & \multicolumn{5}{|c|}{ Ceherb/Faem/Ufpel ${ }^{2}$} \\
\hline & $07 / 12$ & $08 / 12$ & $09 / 12$ & $10 / 12$ & $11 / 12$ & $07 / 13$ & $08 / 13$ & $09 / 13$ & $10 / 13$ & $11 / 13$ \\
\hline Temperature & 7.7 & 12.1 & 11.6 & 14.5 & 15.7 & 11.6 & 11.3 & 15.7 & 17.5 & 20.5 \\
\hline Rainfall & 209.3 & 28.1 & 142.3 & 253.2 & 34.0 & 56.6 & 95.3 & 133.0 & 214.7 & 136.3 \\
\hline
\end{tabular}

Source: ${ }^{1}$ Boletim Agroclimatológico - Laboratório Meteorológico Embrapa Passo Fundo; ${ }^{2}$ Boletim Agroclimatológico - Estação Agroclimatológica de Pelotas. 
dough stage reduced yield compared to the other application time periods. The application of paraquat before the seeds reached physiological maturity contributed to reduction in grain filling, since there was immediate desiccation of the leaves and, consequently, reduction in translocation of photoassimilates to the seeds. This behavior was not observed for the other herbicides because they do not have the ability to rapidly interrupt translocation of the photoassimilates to the seed, as in the case of the herbicide paraquat. In a study conducted by Santos and Vicente (2009), the application of paraquat in the milk grain stage had a negative effect on wheat yield compared to applications in later preharvest periods, corroborating the results obtained in this study.

For the germination test, interaction was found between application rates and application time periods, and interaction between herbicides and application rates (Tables 4 and 5). At the time of application between the milk grain and soft dough stage, both application rates of the herbicides provided a greater percentage of normal seedlings in relation to the treatment without application (Table 4). The same was observed in desiccation in the soft dough to hard dough stage, where the application of herbicides, regardless of the rate, led to values greater than $80 \%$ germination. Nevertheless, in application in the hard dough stage, there was no difference between the application rates of the herbicides and the control. Upon comparing the application time periods within each application rate, greater values of germination were obtained for application in the soft dough to hard dough stage and in the hard dough stage than for application in the milk grain stage, for both application rates. In relation to the control, germination values were greater from application in the hard dough stage, followed by application between the soft grain to hard grain stage, and application between the milk grain to soft dough stage. Wheat seeds from the control treatment from the time period of application in the hard dough stage were reaped with a lower moisture content compared to the other application time periods and were in a stage of complete maturity, which contributed to greater seed germination.

Regardless of the herbicide and the rate applied, there was an increase in the percentage of normal seedlings in comparison to the treatment without application. This can be explained by the action of the desiccating herbicide, which reduces the moisture content of the plant and of the seeds, allowing harvest nearer the point of physiological maturity, the point at which the seed has the greatest accumulation of dry matter and, consequently, the greatest germination potential. Seeds reaped with high moisture content can be damaged during drying because the speed of drying results in rupture or hardening of the seed coat; the seed surface dries rapidly and seals moisture within the inner layers (K'opondo, 2011). High moisture in the inner layers of the seed activate germination and deterioration processes, and reduce the physiological quality of the seeds (Peske et al., 2012). Similar results were obtained by Caierão and Acosta (2007), in which early harvest of barley of treatments with glyphosate and paraquat applied for preharvest desiccation favored the qualitative maintenance of the seeds in relation to the treatment without chemical desiccation.

Germination of the wheat seeds changed according to the herbicide and the application rate (Table 5). At the lower application rate, higher percentages of germination were found when glufosinate, glyphosate, and paraquat+diuron were applied, and these treatments did not differ from each other. At this application rate, a lower percentage of germination was observed in the paraquat treatment compared to the

Table 3. Wheat yield $\left(\mathrm{kg} . \mathrm{ha}^{-1}\right)$ after application of different herbicides in three periods of preharvest desiccation.

\begin{tabular}{cccc}
\hline Herbicide & $\begin{array}{c}\text { Milk grain to } \\
\text { soft dough }\end{array}$ & $\begin{array}{c}\text { Soft dough to } \\
\text { hard dough }\end{array}$ & Hard dough \\
\hline Glufosinate & $2660.7 \mathrm{Aa}$ & $2636.7 \mathrm{Aa}$ & $2607.3 \mathrm{Aa}$ \\
Glyphosate & $2633.7 \mathrm{Aa}$ & $2618.7 \mathrm{Aa}$ & $2611.3 \mathrm{Aa}$ \\
Paraquat & $1962.7 \mathrm{Bb}$ & $2643.3 \mathrm{Aa}$ & $2607.3 \mathrm{Aa}$ \\
Paraquat+Diuron & $2647.0 \mathrm{Aa}$ & $2610.7 \mathrm{Aa}$ & $2571.3 \mathrm{Aa}$ \\
\hline
\end{tabular}

Mean values followed by the same uppercase letters in the columns and lowercase letters in the rows do not differ from each other by the Duncan test $(\mathrm{p} \leq 0.05)$.

Table 4. Final germination (\%) of wheat seeds after application of different rates of glufosinate, glyphosate, paraquat, and paraquat + diuron in three periods of preharvest desiccation.

\begin{tabular}{cccc}
\hline Application rate & $\begin{array}{c}\text { Milk grain to } \\
\text { soft dough }\end{array}$ & $\begin{array}{c}\text { Soft dough to } \\
\text { hard dough }\end{array}$ & Hard dough \\
\hline Control & $58 \mathrm{Bc}$ & $68 \mathrm{Bb}$ & $90 \mathrm{Aa}$ \\
Lower rate & $72 \mathrm{Ab}$ & $84 \mathrm{Aa}$ & $87 \mathrm{Aa}$ \\
Higher rate & $73 \mathrm{Ab}$ & $86 \mathrm{Aa}$ & $89 \mathrm{Aa}$ \\
\hline
\end{tabular}

Mean values followed by the same uppercase letters in the columns and lowercase letters in the rows do not differ from each other by the Duncan test $(\mathrm{p} \leq 0.05)$.

Table 5. Final germination (\%) of wheat seeds desiccated in preharvest with different application rates and herbicides.

\begin{tabular}{cccc}
\hline Herbicide & Control & Lower rate & Higher rate \\
\hline Glufosinate & $72 \mathrm{Ab}$ & $86 \mathrm{Aa}$ & $85 \mathrm{Aa}$ \\
Glyphosate & $72 \mathrm{Aa}$ & $81 \mathrm{ABa}$ & $80 \mathrm{Aa}$ \\
Paraquat & $72 \mathrm{Ab}$ & $73 \mathrm{Bb}$ & $86 \mathrm{Aa}$ \\
Paraquat+Diuron & $72 \mathrm{Aa}$ & $83 \mathrm{Aa}$ & $81 \mathrm{Aa}$ \\
\hline
\end{tabular}

Mean values followed by the same uppercase letters in the columns and lowercase letters in the rows do not differ from each other by the Duncan test $(\mathrm{p} \leq 0.05)$. 
glufosinate and paraquat+diuron treatments. At the higher application rate, no difference was found among the herbicides. In relation to the effect of the application rates of each herbicide on final germination, paraquat at the higher application rate provided a higher percentage of germination compared to the lower rate and the control (Table 5). For glufosinate, both the application rates had higher percentages of germination than the control. Nevertheless, germination of wheat seeds of the glyphosate and paraquat+diuron treatments applied at both rates did not differ from germination of the control treatment.

Desiccation in preharvest with both application rates of all the herbicides, except for the lower application rate of paraquat alone, led to higher values of germination in comparison to the control (Table 5). Bellé et al. (2014) found that preharvest desiccation with paraquat and glyphosate in the 11.2 stage (soft dough) and 11.3 stage (hard dough) led to reduction in the percentage of wheat seed germination in comparison to the control without desiccation, with a greater effect when paraquat was used. These same authors observed that application of either desiccant separately leads to greater leakage of electrolytes and potassium, which indicates damage to membrane integrity, and they are responsible for the reduction in vigor and germination values.

In relation to residue analysis, for glufosinate at the time of application in the milk grain to soft dough stage, the value detected at the lower rate was similar to that at the higher rate (Figure 1). For the time of application in the soft dough to hard dough stage, greater residue was found at the lower rate than the higher rate. However, in application in the hard dough stage, residue of this herbicide was not detected at either of the application rates. In regard to glyphosate residue, the values from the three application times were greater when the lower application rate was used (Figure 1). For paraquat, application at the lower rate in the soft dough to hard dough stage also led to greater accumulation of the herbicide in the seeds, but this accumulation was not found in the time of application in the milk grain to soft dough stage (Figure 1). In the paraquat+diuron treatment, regardless of the application time, there was greater accumulation of paraquat residue when the higher application rate of the mixture was used (Figure 1). Possibly, the greater accumulation of paraquat upon applying the higher application rate of the paraquat+diuron treatment was a result of the greater concentration of the active ingredient, and also because of the diuron herbicide, which assisted in translocation of the paraquat to the wheat seeds (Norsworthy et al., 2011).

In the treatments with glufosinate and paraquat, lower concentration of residues was found compared to applications of the herbicides glyphosate and paraquat+diuron (Figure 1). Hypothetically, in the paraquat and glufosinate treatments, most of the residues detected in the seeds originate from direct deposition of the chemical product, since these products do not have a systemic characteristic, and this explains the lower concentration of these herbicides detected in the wheat seeds. In relation to glyphosate, its systemic characteristic allows it to be translocated to the roots, shoots, and seeds when it is applied on the leaf surface (Duke and Poweles, 2008), which explains its accumulation on wheat seeds. Glyphosate and saflufenacil accumulate in dry edible bean seeds desiccated in preharvest, especially when applied before physiological maturity (McNaughton et al., 2015).

The lower concentration of residue in the seeds coming from the treatments with the higher application rates of the herbicides glyphosate, glufosinate, and paraquat can be

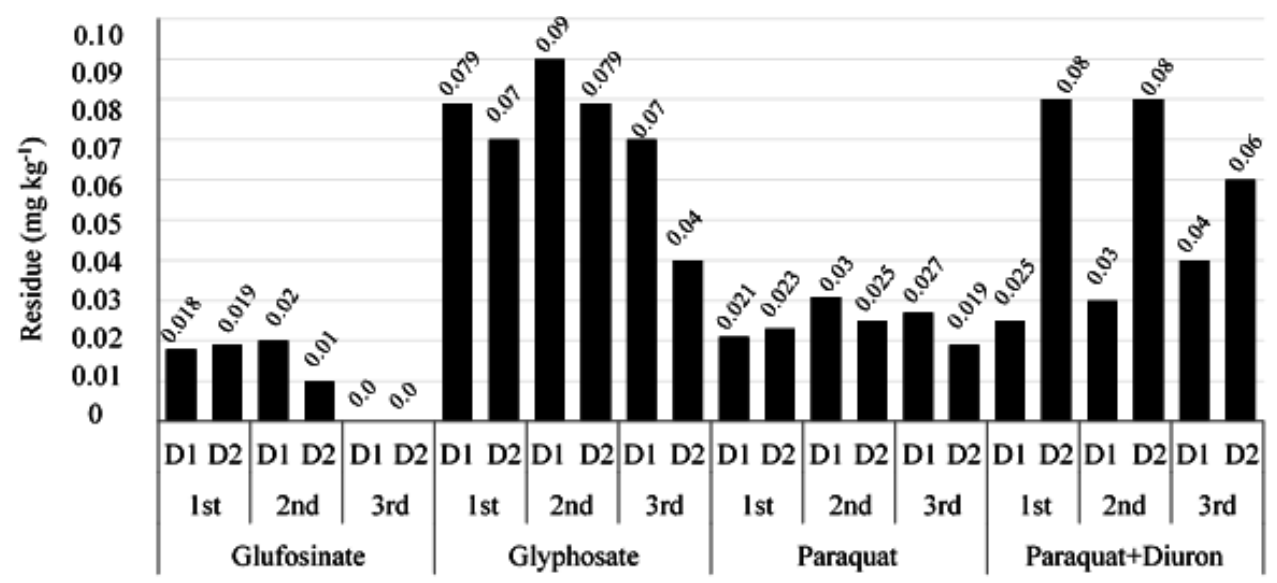

Figure 1. Concentrations (mg. $\mathrm{kg}^{-1}$ ) of glufosinate, glyphosate, and paraquat in wheat seeds under three time periods of preharvest desiccation (1st in milk grain to soft dough stage; 2nd in soft dough to hard dough stage; and 3rd in hard dough stage) and two application rates (D1 = lower rate; $\mathrm{D} 2=$ higher rate). 
explained by their lower translocation from the leaves and stem to the seeds. Higher rates of the herbicides affect or interrupt metabolic routes rapidly compared to lower rates, damaging the leaf tissue and thus reducing or inhibiting translocation of the herbicide to the seeds. According to the agrochemical maximum residue levels (MRL) allowed in wheat seeds, residue values above the MRL were found when paraquat and glyphosate were applied, except for the lower application rate of glyphosate applied in the soft dough to hard dough stage (ANVISA, 2018). The glufosinate residue detected was below the MRL in all the treatments (ANVISA, 2018).

In Trial 2, for the variables 1000 seed weight, yield, and vigor, there was interaction between the application time periods and the harvest timing (Table 6). In the milk grain to soft dough stage, the 1000 seed weight was lower in the first harvest timing in relation to the other harvest timing, whereas in application in the soft dough to hard dough stage, the opposite was observed: the 1000 seed weight was higher in the first harvest timing. Comparing the values of 1000 seed weight among the application time periods, in application in the soft dough to hard dough stage, the 1000 seed weight was higher in the first harvest timing and lower in the third harvest timing in relation to the values of application in the milk grain to soft dough stage. Differences in 1000 seed weight were not observed between the application time periods in the second harvest timing. In the first harvest timing of the milk grain to soft dough herbicide application time, the 1000 seed weight was less, due to interruption of grain filling from the desiccation performed when the wheat seeds had a $40 \%$ moisture content. The decline in 1000 seed weight in the third harvest time period of the soft dough to hard dough herbicide application time period may have occurred as a result of exposure of the seeds to environmental conditions due to their remaining in the field for 15 days after desiccation.

In relation to the yield of wheat desiccated in the milk grain to soft dough stage, lower values were found in the first harvest timing in relation to the other time periods, whereas in herbicide application in the soft dough to hard dough stage, differences were observed in yield in the three harvest timing, with the highest yield being obtained in the second harvest, followed by the third and first harvest timing (Table 6). In reference to the two application time periods, yield values were higher in the soft dough to hard dough application time for all the harvest timing, highlighting that early desiccation interrupted the continuity of grain filling.

Translocation of photoassimilates to the seed is interrupted in early desiccation, due to rapid death of the leaf blade and petiole, affecting 1000 seed weight and yield. The earlier desiccation occurs, the greater the losses will be in seed weight, especially if desiccation occurs before physiological maturity. Preharvest desiccation of wheat with glyphosate in the milk grain stage reduces 1000 seed weight and yield of the crop compared to later desiccation time periods and the control without herbicide application for desiccation (Yenish and Young, 2000). However, Santos and Vicente (2009) showed that desiccation with glufosinate or paraquat in three different phenological stages of application did not affect 1000 seed weight of the wheat cultivar CD 107.

In regard to first germination count in the milk grain to soft dough application time period, a higher value was found in the second harvest timing than in the first and third harvest timing (Table 6). However, in application in the soft dough to hard dough stage, a difference was observed among the three harvest time periods; first germination count was higher in the third harvest timing compared to the first and second harvest timing. In relation to the herbicide application times, the first germination count was higher in the soft dough to hard dough application time for all the harvest time periods. Desiccation in the milk grain to soft dough stage was performed when the seeds were not sufficiently developed, characterized by lower 1000 seed weight, due to interruption of grain filling both from early herbicide application and by early harvest timing, a fact that contributes to reduced vigor in wheat seeds.

Interaction among treatments, application times, and harvest timing was found in final wheat germination count (Table 7). In herbicide application in the milk grain to soft dough stage, comparing the herbicides within each harvest timing, the percentage of germination did not differ among the treatments in the first and third harvest timing. However, in the second harvest timing, the values of germination did not

Table 6. 1000 seed weight, yield, and first germination count of wheat seeds in two preharvest desiccation timing and three harvest timing.

\begin{tabular}{ccc}
\hline \multirow{2}{*}{ Time period } & \multicolumn{2}{c}{1000 seed weight $(\mathrm{g})$} \\
\cline { 2 - 3 } & Milk grain to soft dough & Soft dough to hard dough \\
\hline 1st Harvest & $38.97 \mathrm{Bb}$ & $41.27 \mathrm{Aa}$ \\
2nd Harvest & $40.94 \mathrm{Aa}$ & $40.26 \mathrm{Ba}$ \\
3rd Harvest & $40.74 \mathrm{Aa}$ & $39.69 \mathrm{Bb}$ \\
\hline \multicolumn{2}{c}{ Yield $\left(\mathrm{kg} . \mathrm{ha}^{-1}\right)$} \\
\hline 1st Harvest & $2802.1 \mathrm{Bb}$ & $4095.6 \mathrm{Ca}$ \\
2nd Harvest & $4039.2 \mathrm{Ab}$ & $5932.0 \mathrm{Aa}$ \\
3rd Harvest & $3952.1 \mathrm{Ab}$ & $5429.7 \mathrm{Ba}$ \\
\hline & First germination count (\%) \\
\hline 1st Harvest & $9 \mathrm{Bb}$ & $16 \mathrm{Ca}$ \\
2nd Harvest & $24 \mathrm{Ab}$ & $48 \mathrm{Ba}$ \\
3rd Harvest & $11 \mathrm{Bb}$ & $69 \mathrm{Aa}$ \\
\hline
\end{tabular}

Mean values followed by the same uppercase letters in the columns and lowercase letters in the rows do not differ from each other by the Duncan test and Fisher test $(\mathrm{p} \leq 0.05)$, respectively. 
differ between the herbicides; however, they were superior to the control. Preharvest desiccation provides for qualitative maintenance of seeds compared to treatments without desiccation (Caierão and Acosta, 2007). In application in the soft dough to hard dough stage, final germination was higher in the treatment with glufosinate than in the control or 2,4-D+glyphosate treatment in the first and second harvest (Table 7). No statistical difference was found among the herbicides and control in the third harvest timing. The use of 2,4$\mathrm{D}$ as a desiccant in preharvest is not very common compared to the herbicides glufosinate, glyphosate, and paraquat; however, its use is possible for control of weeds resistant to glyphosate, such as horseweed (Conyza bonariensis).

In relation to harvest timing within each herbicide application time period and each treatment, in application in the milk grain to soft dough stage, final germination count of wheat was generally higher in the second harvest timing than in the first and third harvest timing for glufosinate and 2,4-D+glyphosate, while for the control, no difference was observed among the harvest timing (Table 7). In application in the soft dough to hard dough stage, the germination percentage in the glyphosate+2,4-D and control treatments was higher in the third harvest than in the second and first harvest timing (Table 7). For glufosinate, the percentages of germination of the seeds in the second and third harvest timing did not differ from each other; nevertheless, they were higher than from the first harvest timing. In general, comparing the two time periods of application, higher values of germination were observed in application in the soft dough to hard dough stage for the second and third harvest timing, whereas in the first harvest, there was no difference between the herbicide application time periods.

In general, germination was more affected when herbicide application was made in the milk grain to soft dough stage. Considering that physiological maturity corresponds to the moisture content of $30 \%$ (Peske et al., 2012), herbicide application in the milk grain to soft dough stage was before the seed reached physiological maturity, a fact that contributed to reduction in physiological quality. Applications of paraquat at 23 and 33 days after flowering (DAF) lead to reduction in the percentage of wheat germination compared to 40 DAF (Santos and Vicente, 2009). Harvest near the time of application of desiccants and seeds remaining in the field after application in the milk grain to soft dough stage reduced first germination and final germination count of wheat (Tables 6 and 7). Seeds remaining in the field for a prolonged period after maturity may bring about significant declines in the seed quality and yield. After physiological maturity, the physiological quality of seeds tends to decrease in accordance with degenerative processes of a physical, physiological, or biochemical nature, characterizing the deterioration process (Peske et al., 2012).

Residue analysis showed residues of glyphosate and 2,4-D (Figure 2). Glyphosate was detected at concentrations below the quantification limit in the two herbicide application time periods and three harvest time periods. Translocation of glyphosate follows the same route of the sugars produced in photosynthesis, being displaced from the location of application to the parts of the plant with high metabolic activity (Duke and Poweles, 2008). Since glyphosate translocates to parts with high metabolic activity, there is the possibility of being translocated to seeds in development (McNaughton et al., 2015). Residues of 2,4-D were detected in all the samples, and similar behavior was observed for the two time periods of application, in which the concentration of 2,4-D was lower in the first and third harvest timing compared to the second (Figure 2). According to the maximum residue level of 2,4-D allowed in wheat seeds, all the treatments exhibited values below the MRL (ANVISA, 2018).

After uptake by plants, 2,4-D moves from the xylem and phloem and is distributed to the meristems and other organs in development (Oliveira Júnior, 2011). The physiological stage of the plant at the time of application of the herbicides affects the magnitude of the residue in the wheat seed, i.e., when desiccation occurs in the milk grain to soft dough stage, there is a high flow of photoassimilates to sinks, and it is expected that after absorption of the herbicide, it is translocated to the seeds in development (McNaughton et al., 2015). When desiccation with herbicides is performed near harvest time, i.e., when the crop has physiologically mature seeds, translocation does not occur, and only surface residues are detected, as a result of

Table 7. Final germination (\%) in two preharvest desiccation timing and three harvest timing.

\begin{tabular}{|c|c|c|c|c|c|c|}
\hline \multirow{2}{*}{ Treat. } & \multicolumn{3}{|c|}{ Milk grain to soft dough } & \multicolumn{3}{|c|}{ Soft dough to hard dough } \\
\hline & 1st Harvest & 2nd Harvest & 3rd Harvest & 1st Harvest & 2nd Harvest & 3rd Harvest \\
\hline $\mathrm{T}^{1}{ }^{1}$ & $44 \mathrm{Aa} \alpha$ & $49 \mathrm{Ba} \beta$ & $47 \mathrm{Aa} \beta$ & $43 \mathrm{Bc} \alpha$ & $68 \mathrm{ABb} \alpha$ & 79 Aa $\alpha$ \\
\hline $\mathrm{T} 2$ & $47 \mathrm{Ab} \alpha$ & 63 Aa $\alpha$ & $43 \mathrm{Ab} \beta$ & $52 \mathrm{ABb} \alpha$ & $60 \mathrm{Bb} \alpha$ & 76 Aa $\alpha$ \\
\hline $\mathrm{T} 3$ & $52 \mathrm{Aab} \alpha$ & $61 \mathrm{Aa} \beta$ & $45 \mathrm{Ab} \beta$ & $55 \mathrm{Ab} \alpha$ & 74 Аа $\alpha$ & 75 Aa $\alpha$ \\
\hline
\end{tabular}

${ }^{1} \mathrm{~T} 1=$ control, $\mathrm{T} 2=2,4-\mathrm{D}+$ glyphosate, and T3 = glufosinate; Mean values followed by the same uppercase letters in the columns and lowercase letters in the rows do not differ from each other by the Duncan test $(\mathrm{p} \leq 0.05)$. Mean values followed by a Greek letter compare herbicide application time periods in each harvest timing by the Fisher test $(\mathrm{p} \leq 0.05)$. 


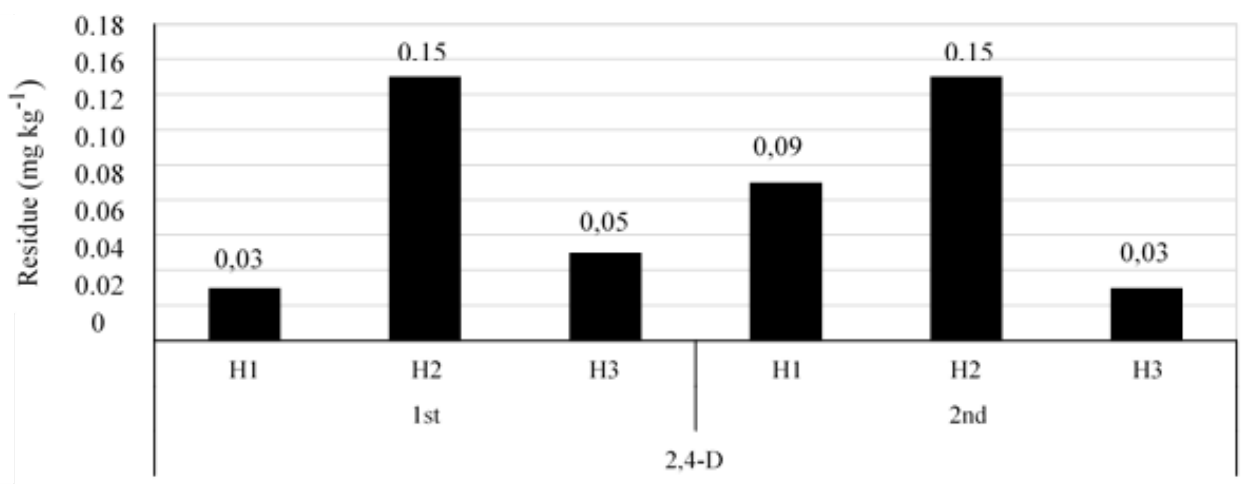

Figure 2. Concentrations $\left(\mathrm{mg}^{\mathrm{kg}} \mathrm{kg}^{-1}\right)$ of 2,4-D in wheat seeds under two time periods of preharvest desiccation (1st in milk grain to soft dough stage, and 2nd in soft dough to hard dough stage) and three harvest timing ( $\mathrm{H} 1=$ first harvest; $\mathrm{H} 2=$ second harvest; $\mathrm{H} 3$ = third harvest).

direct deposition of the herbicide (Cessna and Holm, 1994). In addition, what may bring about determined residual levels is the time interval between herbicide applications and harvest.

Delay in wheat harvest after desiccation led to reduction in 2,4-D residue. Cessna and Holm (1994) showed that 2,4$\mathrm{D}$ applied in the milk grain stage of wheat accumulated less in the straw and seeds when the wheat was reaped at maturity compared to wheat reaped in the hard dough stage. According to the authors, in addition to possible metabolism in the seed and decomposition, the decrease in residue may also be attributed to the occurrence of high rainfall. Glufosinate was not detected in the wheat samples because its rapid phytotoxicity prevents its translocation to wheat seeds (Everman et al., 2009).

\section{Conclusions}

Paraquat, regardless of the application rate, applied in the milk grain to soft dough stage reduces wheat yield. Preharvest desiccation, regardless of the herbicide and application rate, performed in the milk grain to soft dough stage and soft dough to hard dough stage leads to greater germination of wheat seeds, except for paraquat at the low application rate. The higher application rate of paraquat + diuron leads to greater accumulation of paraquat residue in the seeds. Glyphosate, regardless of the application rate, accumulates more compared to paraquat and glufosinate.

Desiccation in the milk grain to soft dough stage, regardless of the herbicide, reduces the yield and vigor of wheat seeds. 2,4-D+glyphosate reduces germination of wheat seeds when applied in the soft dough to hard dough stage. The residues of 2,4-D detected are below the maximum level allowed in all the herbicide application and harvest timing. Preharvest desiccation with systemic herbicides leads to greater accumulation of residues in wheat seeds.

\section{References}

AGROFIT. Sistema de agrotóxicos fitossanitários. http://agrofit. agricultura.gov.br/agrofit_cons/principal_agrofit_cons. Accessed on: Jan $15^{\text {th }} 2018$.

ANVISA. Agência Nacional de Vigilância Sanitária. http://portal. anvisa.gov.br/registros-e-autorizacoes/agrotoxicos/produtos/ monografia-de-agrotoxicos/autorizadas. Accessed on April 17 2018.

BELLÉ, C.; KULCZYNSKI, S.T.; BASSO, C.J.; KASPARY, T.E.; LAMEGO, F.P.; PINTO, M.A.B. Yield and quality of wheat seeds as a function of desiccation stages and herbicides. Journal of Seed Science, v.36, p.63-70, 2014. http://www.scielo.br/scielo.php?pid $=\mathrm{S} 2317-15372017000300254 \&$ script $=$ sci_arttext

BIANCHI, M.A.; FLECK, N.G.; AGOSTINETTO, D.; RIZZARDI, M.A. Interferência de Raphanus sativus na produtividade de cultivares de soja. Planta Daninha, v.29, p.783-792, 2011. http://www.scielo. br/scielo.php?script $=$ sci_arttext\&pid $=$ S0100-83582011000400008

BRASIL. Ministério da Agricultura, Pecuária e Abastecimento. Regras para análise de sementes. Brasília: MAPA/ACS, 2009. 399p.

CAIERÃO, E.; ACOSTA, A.S. Uso industrial de grãos de cevada de lavouras dessecadas em pré-colheita. Pesquisa Agropecuária Brasileira, v.42, p.1277-1282, 2007. https://www.alice.cnptia. embrapa.br/bitstream/doc/822233/1/42n09a09.pdf

CESSNA, A.J.; HOLM, F.A. Residues of 2,4-D in wheat following application after heading. Canadian Journal Plant Science, v.74, p.199-203, 1994. http://www.nrcresearchpress.com/doi/abs/ 10.4141/ cjps93-051\#.Wnc-PqinHIU

COMISSÃO BRASILEIRA DE PESQUISA DE TRIGO E TRITICALE. Informações técnicas para trigo e triticale - safra 2012. Dourados: CPAO, 2011. 204p.

DUKE, S.O.; POWLES, S.B. Glyphosate: A once-in-a-century herbicide. Pest Management Science, v.64, p.319-325, 2008. https:// www.ncbi.nlm.nih.gov/pubmed/18273882 
EVERMAN, W.J.; THOMAS, W.E.; BURTON, J.D.; YORK, A.C.; WILCUT, J.W. Absorption, translocation, and metabolism of glufosinate in transgenic and nontransgenic cotton, palmer amaranth (Amaranthus palmeri), and pitted morningglory (Ipomoea lacunosa). Weed Science, v.57, p.357-361, 2009. http://www.bioone. org/doi/abs/10.1614/WS-09-015.1

GRIFFIN, J.L.; BOUDREAUX, J.M.; MILLER, D.K. Herbicides as harvest aids. Weed Science, v.58, p.355-358, 2010. http://www. bioone.org/doi/abs/10.1614/ws-09-108.1

JASKULSKI, D.; JASKULSKA, I. The effect of pre-harvest glyphosate application on grain quality and volunteer winter wheat. Romanian Agricultural Research, v.31, p.283-289, 2014. https:// www. researchgate.net/publication/286226726

K'OPONDO, F.B.O. Influence of drying method and fruit position on the mother plant on seed quality of spiderplant (Cleome gynandra L.) morphotypes from western Kenya. Advances in Applied Science Research, v.3, p.74-83, 2011. http://www.imedpub.com/articles/ influence-of-drying-method-and-fruit-position-on-the-mother-plant-onseed-quality-of-spiderplant-cleome-gynandra-l-morphotypes-fro.pdf

MCNAUGHTON, K.E.; BLACKSHAW, R.E.; WADDELL, K.A.; GULDEN, R.H.; SIKKEMA, P.H.; GILLARD, C.L. Effect of application timing of glyphosate and saflufenacil as desiccants in dry edible bean (Phaseolus vulgaris L.). Canadian Journal Plant Science, v.95, p.369-375, 2015. http://www.bioone.org/doi/ abs/10.1139/CJPS-2014-157

MIDIO, A.F.; MARTINS, D.I. Herbicidas em Alimentos. São Paulo: Editora Varela, 1997. 109pp.
NORSWORTHY, J.K.; SMITH, K.L.; GRIFFITH, G. Evaluation of combinations of paraquat plus photosystem II-inhibiting herbicides for controlling failed stands of maize (Zea mays). Crop Protection, v.30, p.307-310, 2011. https://www.sciencedirect.com/science/ article/pii /S0261219410 003388

OLIVEIRA JUNIOR, R.S.; Mecanismo de Ação de Herbicidas. In: OLIVEIRA JUNIOR, R.S.; CONSTANTIN, J.; INOUE, M. H. (Eds.). Biologia e Manejo de Plantas Daninhas. Curitiba: Omnipax, 2011. p.141-192.

PESKE, S.T.; VILLELA, F.A.; MENEGHELLO, G.E. Sementes: Fundamentos Científicos e Tecnológicos. 2 ed. Pelotas: Universitária/ UFPel, 2012. 573p.

SANTOS, P.R.R.; VICENTE, D. Momento fisiológico das plantas de trigo para a dessecação e seus efeitos no rendimento de grãos. Cultivando o Saber, v.2, p.52-62, 2009. https://www.fag.edu.br/ upload/revista/cultivando_o_saber/591a1fee7d5fb.pdf

SUBEDI, M.; WILLENBORG, C.J.; VANDENBERG, A. Influence of harvest aid herbicides on seed germination, seedling vigor and milling quality traits of red lentil (Lens culinaris L.). Frontiers in Plant Science, v.8, p.311, 2017. 10.3389/fpls.2017.00311

YENISH, J.P.; YOUNG, F.L. Effect of preharvest glyphosate application on seed and seedling quality of spring wheat (Triticum aestivum). Weed Technology, v.14, p.212-217, 2000. https://doi. org/10.1614/0890-037X(2000)014[0212:EOPGAO]2.0.CO;2

ZADOKS, J.C.; CHANG, T.T.; KONZAK, C.F. A decimal code for the growth stages of cereals. Weed Research, v.14, p.415-421, 1974. http://old.ibpdev.net/sites/default/files/zadoks_scale_1974.pdf 